\title{
MAINSTREAMING CLIMATE CHANGE. ADAPTATION INTO REGIONAL PLANNING OF LEAST DEVELOPED COUNTRIES: STRATEGY IMPLICATIONS FOR REGIONS IN BANGLADESH
}

\author{
Rakibul, ALAM ${ }^{1}$ and Khalid Md., BAHAUDDIN ${ }^{2}$ \\ ${ }^{1}$ Institute of Advanced Research, Indonesia, rakibulalam761@gmail.com \\ ${ }^{2}$ Bangladesh Society of Environmental Scientists, Bangladesh
}

\begin{abstract}
The purpose of the study is to assess the search for mainstreaming climate change adaptation into regional planning of least developed countries (LDCs) and draw strategy implications for regions in Bangladesh. The findings of the study revealed that national adaptation programme of action (NAPAs) in least developed countries were being gender-blind and failed to be properly implemented. Least developed countries should therefore do more to prepare for ongoing and future climate changes focusing on actions that are no-regrets, multi-sectoral and multi-level, and that improve the management of current climate variability. Strengthening capacities to use climate information, enabling locally appropriate responses, screening climate risks, assessing risks and adaptation options, starting with existing policies and plans, broadening constituencies beyond environment agencies, managing strategy conflicts, learning from projects and recognizing their limitations, monitoring and learning are the foreseen strategic actions by regions in Bangladesh for effective mainstreaming of climate change adaptation into regional development planning in the years to come.
\end{abstract}

KEYWORDS: Climate Change, Adaptation, Bangladesh, Least Developed Countries, Mainstreaming

\section{INTRODUCTION}

Regional planning draws on perspectives from the broad fields of economics, geography, town planning and organizational development and integrated regional economic-cumenvironmental development plans are expected to show the linkages among economic development, resource use and the production of residuals and impacts on environmental quality and communities (Gabriel and Laugesen, 2000; Batabyal and Nijkamp, 2004; Church, 2010; Krueger, 2010; Mason, 2011). Scholars in regional planning contend that environmental concerns should be properly addressed in regional planning. For instance, Roberts (2006) asserts that the integration of environmental concerns within regional planning aims to reduce the possibility of any dislocation between environmental, economic and spatial processes.

Regional planning usually takes place at both the national and regional levels. According to Gabriel and Laugesen (2000), regional planning from national perspective is concerned with optimizing the use of national space in development process while it is concerned with using regional resources in a way that maximises the benefits to the economy and population of the region from regional perspective. A country is seen as "a system of regions, each of which constitutes a distinct geographic, socioeconomic, functional or administrative component of national space and each of which comprises a system of settlements and hinterland areas".

The regional planner at the national level often concentrates on the interregional implications of patterns of development in the different regions (Gabriel and Laugesen, 2000). Regional planners are much concerned about the sustainable development of a given region. For example, Roberts (2006) contends that regional planners have to persist in pursuit of the goal of sustainable development as their key responsibility is to search for sustainable solutions to the planning of regions.

According to Karl and Ranne (2001), the tasks of regional planning include the definition of legally binding goals in the form of regional plans, the co-ordination of the activities of relevant government departments, town and country planning procedures and environmental impact assessments in the case of private and public projects that affect the environment or the surrounding location.

They also assert that regional development planning specifies goals both in terms of content and location. Climate change in this paper refers to a change of climate which is attributed directly or indirectly to human activity that alters the composition of the global atmosphere and which is, in addition to natural climate variability, observed over comparable time periods (United Nations, 1992; IPCC, 2007). Vulnerability to impacts of climate change in this paper refers to the lack of capacity to adapt and to respond to stress as a result of climate variability or change, with a consequent decline in well-being (Adger et al., 2002; Huq et al., 2003; Brooks et al., 2004; Downing, et al., 2004; IPCC, 2007; Huxtable and Yen, 2009; Yaro et al., 2010; Nelson, 2011; UNPEI, 2011).

Adaptive capacity in this paper refers to the ability of a system to adjust to climate change (including climate variability and extremes) to moderate potential damages, to take advantage of opportunities, or to cope with the consequences (Claire et al., 2002; Adger et al, 2003; Huq et al., 2003; Downing, et al., 2004; Ebi et al., 2004; Brooks et al., 2004; Eriksen et al., 2005; Huxtable and Yen, 2009; Nelson, 2011). Resilience in this paper refers to the ability of a community to resist, absorb, and recover from the effects of hazards in a timely and efficient manner, preserving or restoring its essential basic structures, functions and identity (Huxtable and Yen, 2009; Nelson, 2011). Hazard in this paper refers to shocks, such as droughts 
or floods (rapid onset), and to stresses, such as changing rainfall patterns (slow onset) (Huxtable and Yen, 2009).

There are two main ways of responding to climate change: mitigation and adaptation (Adger et al, 2003; Klein et al., 2003; Lim et al., 2004; Lebel et al., 2012). Mitigation may be defined as "an anthropogenic intervention to reduce the anthropogenic forcing of the climate system, which includes strategies to reduce greenhouse gas sources and emissions and enhancing greenhouse gas sinks" while adaptation may be defined as "adjustment in natural or human systems in response to actual or expected climatic stimuli or their effects, which moderates harm or exploits beneficial opportunities" (IPCC, 2007). Adaptation to climate change entails adjusting ecological or social systems in response to minimise damages from climate change (Schipper et al., 2010; Lebel et al., 2012). Mainstreaming climate change adaptation has got scientific and political attention in our current world as effective climate change adaptation approach in Least Developed Countries (LDCs). Mainstreaming climate change adaptation in this paper refers to integrating considerations of climate change adaptation into policymaking, budgeting, implementation and monitoring processes at national, sector and subnational/regional levels (UNDP-UNEP, 2011 cited in Lebel et al., 2012). The process is seen as on-going, involving multiple stakeholders and contributing to human well-being (Lebel et al., 2012).

Threat of global climate change is one of the most significant scientific and political challenges of our time (Betsill and Bulkeley, 2006). Climate change is expected to increase the frequency and intensity of current hazards and the probability of extreme events, and also to spur the emergence of new hazards and new vulnerabilities with differential spatial and socioeconomic impacts (Revi, 2008). For example, based on the most recent information, mainly from simulations of GCMs, it is believed that the average global temperature of the earth will be between $1.4^{\circ} \mathrm{C}$ to $5.8^{\circ} \mathrm{C}$ warmer than it is currently by the end of the 21 st century (Jones, et al., 2004). Moreover, there is increasing evidence that the warming of the earth over the past 50 years is attributable to increased greenhouse gases resulting from human activities (Jones, et al., 2004). As global climate change is unfolding, its effects are being felt disproportionately in the world's poorest countries (Least Developed Countries) and among the groups of people least able to cope. As the world adapts to its evolving climate, more global attention is now being focused on adaptation to the effects of climate change (Kidanu et al., 2009). In other words, there is growing concern about the impacts of climate extreme events (floods, cyclones, droughts, etc.), especially among the least developed countries, given their very limited capacity to adapt and recover from such disasters.

Careful analysis of the current situation in light of how climate variability and extremes might change is necessary before informed adaptation activities can be undertaken. Mainstreaming adaptation to climate change into development planning is being promoted as effective adaptation approach in LDCs and this necessitates careful understanding of vulnerabilities and adaptive capacities of vulnerable communities in LDCs. Hence, this paper proposes to explore the quest for mainstreaming climate change adaptation into Regional Planning in LDCs and draw strategy implications for regions in Bangladesh. The specific objectives of the study are: to explore vulnerabilities to impacts of climate change in LDCs; to appraise climate change adaptation policies and strategies in LDCs; to assess the benefits of mainstreaming climate change adaptation into regional planning; and to identify the role of regional planning in climate change adaptation in LDCs.

The study answered the following key research questions: What are the types of vulnerabilities to impacts of climate change and vulnerable sectors in LDCs? How much effective are climate change adaptation policies and strategies in LDCs? What are the benefits of mainstreaming climate change adaptation into regional planning? What is the role of regional planning in climate change adaptation in LDCs? What are the lessons from a case study on best practices of mainstreaming climate change adaptation into regional planning? What are the strategy implications for regions in Bangladesh on mainstreaming climate change adaptation into regional planning?

\section{VULNERABILITIES TO IMPACTS OF CLIMATE CHANGE IN LEAST DEVELOPED COUNTRIES}

Vulnerability to climate change refers to the degree to which groups of people and livelihood systems are susceptible to, and unable to cope with, adverse impacts (Claire et al., 2002; Adger et al, 2003; Huxtable and Yen, 2009; Yaro et al., 2010). Scholars of climate change research contend that the vulnerability of a system includes both an external dimension, represented by its exposure to climate change and variability, and an internal dimension, represented by its sensitivity to these factors and its adaptive capacity (USAID, 2004; Eriksen et al., 2005; Fu"ssel, 2007; ECE, 2009; Heltberg et al., 2009; Nelson, 2011; UNPEI, 2011). Moreover, some of these scholars assert that it is necessary to distinguish between current and future vulnerability. For example, Tompkins and Adger, 2003; Downing, et al., 2004; Jones, et al., 2004; Malone and Rovere, 2004 claim that current vulnerability relates to current climate variability, independent of future changes in climate, and the ability of the system to cope with this variability. ECE (2009) affirms that assessing current vulnerability provides important insights into the potential responses of the system to future events. Future vulnerability relates to future climate conditions and coping ability under a situation with a changing baseline and more severe and frequent extreme events (Downing, et al., 2004; Jones, et al., 2004; ECE, 2009). There are also scholars who contend that vulnerability has not only physical aspects but also geographical, social, economic, environmental and psychological aspects that need to be taken into account (Tompkins and Adger, 2003; Downing, et al., 2004; Malone and Rovere, 2004; USAID, 2004; Eriksen et al., 2005; Haines et al., 2006; ECE, 2009; Kidanu et al., 2009; Nelson, 2011).

Human vulnerability to disasters in LDCs is a complex phenomenon that includes social, economic, health, and cultural factors. Moreover, vulnerability to natural disasters has two sides: the degree of exposure to dangerous hazards (susceptibility) and the capacity to cope with or recover from the consequences of disasters (resilience) (Keim, 2008; Huxtable and Yen, 2009; Yaro et al., 2010). Vulnerability reduction programs reduce susceptibility and increase resilience (Keim, 2008; Huxtable and Yen, 2009).

According to Schipper et al. (2010), numerous factors determine vulnerability to climate change in LDCs, including geographical location, gender, age, political affiliation, livelihood, access to resources and wealth (entitlements), etc. In other words, vulnerability to climate change is not uniform, but differs according to the sociocultural axes of a society (Denton, 2002; Downing, et al., 2004; Aalst and Burton, 2008; 
Huxtable and Yen, 2009; Elasha, 2010; Nelson, 2011; Oates et al., 2011). For instance, social differentiation and access to resources as enabled by both formal and informal institutions accounts for the differential adaptations people face in their communities (Schipper et al., 2010). The nature of the inheritance system, governance systems, and land tenure relations are important in this regard (Schipper et al., 2010; Lebel et al., 2012). Socioeconomic processes lead to the exclusion of some people from mainstream society. For example, climate-enhanced social exclusion is increasing, as evidenced by the increasing number of "environmental refugees" generated by each climate hazard (Mirza, 2003; Keim, 2008; Huxtable and Yen, 2009; Yaro et al., 2010).

Climate change poses a serious challenge to social and economic development (USAID, 2004). Least Developed Countries (LDCs) are particularly vulnerable because their economies are generally more dependent on climate-sensitive natural resources, and because they are less able to cope with the impacts of climate change. Moreover, the effects of climate change may be especially critical to the achievement of development objectives related to the most vulnerable groups and communities in these countries (Elasha, 2010; Nelson, 2011). Thus, the projected impact of climate change on access to natural resources, heat-related mortality and spread of vector-borne diseases such as malaria, for example, has direct implications for the achievement of several of the Millennium Development Goals (Pandey, et al., 2003; Gigli and Agrawala, 2007). Lebel et al. (2012) claim that the rural poor in less developed countries are vulnerable, as they depend on the productivity of climate-sensitive ecosystems for their livelihoods, including agriculture and fishery while the urban poor are vulnerable to infrastructure and land development decisions that drive settlements into areas that are already exposed to flooding, landslides, and other climate-related disasters, or likely to become so.

They also assert that in both realms, poverty hinders access to education, health care and other important services and resources. Additionally, poor countries often lack the knowledge and resources to adequately adapt to growing climate-related risks, building up an "adaptation deficit". Effects on women and children are also disproportionate compared to men in these countries (Mirza, 2003; Kidanu et al., 2009; Elasha, 2010; Nelson, 2011). Moreover, because of gender differences in property rights, access to information and social and economic roles, the effects of climate change will affect men and women differently (Huxtable and Yen, 2009; Elasha, 2010; Nelson, 2011).

\section{CLIMATE CHANGE ADAPTATION POLICIES AND STRATEGIES IN LEAST DEVELOPED COUNTRIES}

Adaptation to climate change has become an important policy priority in the international negotiations on climate change in recent years. However, it has yet to become a major policy issue within the developing countries, especially amongst the LDCs (who will be amongst the most vulnerable to the adverse impacts of climate change) (Huq et al., 2003). Climate change could significantly undermine development by threatening critical resources, especially water, and increasing the incidence and severity of natural disasters (Huxtable and Yen, 2009; Lebel et al., 2012). More recently, in recognition that some climate impacts are now unavoidable, there has been a growing push for adaptation, in effectively responding to climate change to minimize impacts on both people and ecosystems (IPCC, 2007; Lebel et al., 2012).
One of the results of this growing push for adaptation is National Adaptation Programme of Action (NAPA). NAPA is an adaptation initiative that aims at building the adaptive capacity of the most vulnerable communities in the most vulnerable countries (identified as the Least Developed Countries or LDCs), through the identification and development of specific measures aimed at reducing vulnerabilities to climate change of the different groups and sectors. Based on this, the main objective of the NAPA is to serve as a simplified and direct channel of communication for information related to the urgent and immediate adaptation needs of the LDCs (Elasha, 2010). A set of criteria for selecting priority activities in the NAPAs were (Mirza, 2003, 237): life and livelihood, human health, food security and agriculture, water availability, quality and accessibility, essential infrastructure, cultural heritage, biological diversity, land management, other environmental amenities and other socio-economic factors, especially poverty.

Though there is a good progress resulting from NAPAs initiatives in some least developed countries, NAPAs are criticized for being gender-blind and failed to be properly implemented. With regard to its gender-blindness, Elasha (2010) contends that none of the National Adaptation Programme of Action (NAPA) projects in LDCs specifically target women development and capacity building in order to improve their contribution to the community's adaptation. Despite this negligence, scholars of climate change research like Nelson (2011) asserts that the impacts of climate change are affecting and will affect disproportionately poorer rural and urban communities in developing countries, but few of the vulnerability and adaptation assessments adequately explore the gendered or socially differentiated nature of those impacts.

To overcome the aforementioned challenges, current climate change adaptation approaches like mainstreaming climate change adaptation encourage participation of stakeholders and gender consideration in the adaptation policy and strategy formulations. The benefit of participating both women and men is that they have distinct and valuable knowledge about how to adapt to the adverse impacts of climate change (Thomasa and Twyman, 2005; Huxtable and Yen, 2009). For example, as primary managers of natural resources and key frontline implementers of development, women in LDCs represent an immense source of potential knowledge and skills to build the adaptive capacity of their communities (Huxtable and Yen, 2009). It is also evident that women play a major role in buffering the family against unexpected climatic shocks. Their knowledge of local people and ecosystems, their skills and abilities, social networks and community organizations help communities mitigate hazardous conditions and events and respond effectively to disasters when they occur (Elasha, 2010). Clearly, there is a gender dimension to adaptive capacity as gender discrimination presents barriers to women's equal participation in many decision-making processes and access to education and skills training (Thomasa and Twyman, 2005; Nelson, 2011). Lebel et al. (2012) contend that mainstreaming adaptation into development planning in least developed countries (LDCs) has to consider at least national, sectoral and sub-national/regional levels. Climate change adaptation policies need not develop specific and detailed response options, but rather facilitate their development and implementation as part of existing sectoral policies (Heltberg et al., 2009; Lebel et al., 2012). Hardoyand Pandiella (2009) assert that actions that integrate an understanding of the links between environmental problems (including climate change and variability) and development have the greatest potential to 
generate multiple benefits and provide the kind of measures most needed. They further contend that most of the best adaptation options are those that would be taken even in the absence of climate change because of their contribution to risk reduction and sustainable development.

Political commitment at all levels to participate stakeholders and take gender seriously in combating climate change would make the most difference in achieving fair and genderequitable finance mechanisms (Thomasa and Twyman, 2005). To build women's participation in national climate change adaptation planning, participatory processes are required that enable diverse groups of disadvantaged women's as well as men's voices to be heard by policy-makers (Adger et al., 2002; Denton, 2002; Bulkeley and Mol, 2003; Brooks et al., 2004; Conde et al., 2004; Ebi et al., 2004; Turnpenny et al., 2005; Few and Tompkins, 2006; Elasha, 2010; Nelson, 2011). There is little point in envisioning future pathways that lead to climate resilience, without seeking gender and social equality: in fact it is surely impossible to achieve resilience without tackling the latter (Nelson, 2011).

Adaptation science and practice have promoted the concept of community-based adaptation, which is locally focused, participatory, and draws on the normative preferences and knowledge of local people (Measham, et al., 2011). As the UNFCCC moves forward with discussions on longer-term adaptation strategies, it should support strategies that foster integrated approaches to strengthening resilience to the effects of climate change (Kidanu et al., 2009). International institutions need to appropriate these latest research insights on adaptation from the developing world and build a global coalition, not only to take action to reduce damaging emissions, but to facilitate the inherent resilience of people coping with an uncertain future (Adger et al., 2002). In many least developed countries climate change adaptation and poverty reduction remain separate strategies and there is a danger that adaptation is being addressed in a fragmented manner. There is a need to build on existing initiatives such as the NAPAs and national (and sectoral) development plans, and to consolidate donor and government efforts, rather than creating new projects or programmes (Oates et al., 2011).

\section{BENEFITS OF MAINSTREAMING CLIMATE CHANGE ADAPTATION INTO REGIONAL PLANNING OF LEAST DEVELOPED COUNTRIES}

According to UNPEI (2011), mainstreaming climate change adaptation is the iterative process of integrating considerations of climate change adaptation into policymaking, budgeting, implementation and monitoring processes at national, sector and sub-national/regional levels. In other words, it describes a process of considering climate risks to development projects, and of adjusting project activities and approaches to address these risks (Huxtable and Yen, 2009). It is a multi-year, multistakeholder effort grounded in the contribution of climate change adaptation to human well-being, pro-poor economic growth, and achievement of the MDGs (Huxtable and Yen, 2009; UNPEI, 2011). It entails working with a range of government and nongovernmental actors, and other actors in the development field (UNPEI, 2011).

Mainstreaming climate risks into the national development agenda reduces the devastating consequences of unanticipated climate-related hazards, including costs that constitute significant drains on national resources, thereby stifling the achievement of set goals (Klein et al., 2003; Jones, et al., 2004;
Kok et al., 2008; Yaro et al., 2010). It can also ensure that development programs and policies are not at odds with climate risks both now and in the future (Huxtable and Yen, 2009; Chinvanno, 2011). There is a growing need for policymakers, particularly in the ministries related to development such as in finance or planning, to better understand how climate change adaptation can be addressed in national and sub-national/regional planning processes, and through fiscal and investment decisions.

For example, when making decisions on long-lived infrastructure, it may be more cost-effective to take adaptation needs into account earlier rather than later (Lebel et al., 2012). Mitigation actions tackle the causes of climate change and their benefits are always global while adaptation actions are undertaken at the local or regional level and their benefits are at these levels (Lebel et al., 2012). Gigli and Agrawala (2007) contend that adaptation to the impacts of climate variability and climate change needs to be brought into the mainstream of economic policies, development projects, and international aid efforts. They also assert that the implications of climate variability and change must be considered on a variety of development activities including poverty alleviation, sectoral development, and natural resource management at policy level. While some of the threats from climate change may be new, such as unprecedented climate conditions, many aspects of adaptation build on longstanding efforts, such as to reduce the risk of disaster or protect vulnerable coasts (Füssel, 2007; Lebel et al., 2012; Oates et al., 2011). In other words, adaptation has the potential to align closely with major development objectives.

Mainstreaming climate change adaptation can occur at the strategic level or the operational level (Huxtable and Yen, 2009; Oates et al., 2011). Mainstreaming climate change adaptation at the strategic level addresses the organisational environment in which policies and programmes are developed and implemented. A strategy to integrate climate change concerns into programming must be accompanied by a strategy to ensure that the working environment is sensitive to climate change issues (e.g. consideration of climate related issues in budgets), and sufficient technical capacity and human resources to successfully mainstream climate change adaptation must be made available (Huxtable and Yen, 2009; Oates et al., 2011).

Mainstreaming at the operational level involves undertaking an evaluation of risks to poverty reduction activities associated with climate variability and change, and identifying effective, efficient and equitable adaptation measures to reduce those risks and harness opportunities for building adaptive capacity (Huxtable and Yen, 2009; Oates et al., 2011).

In a nut-shell, mainstreaming adaptation into development planning has been promoted as an effective way to respond to climate change and the expected benefits for less developed countries include: avoided policy conflicts; reduced risks and vulnerability; greater efficiency compared with managing adaptation separately; leveraging the much larger financial flows in sectors affected by climate risks than the amounts available for financing adaptation separately, and easier to start with existing policies and practices, rather than creating new ones (Klein et al., 2003; Huxtable and Yen, 2009; King, 2010; Chinvanno, 2011; Oates et al., 2011; UNPEI, 2011;Lebel et al., 2012). 


\section{THE ROLE OF REGIONAL PLANNING IN CLIMATE CHANGE ADAPTATION IN LEAST DEVELOPED COUNTRIES}

In recent years much has been written on the subject of vulnerabilities to impacts of climate change and adaptations in least developed countries. But, little has been said about the role of regional planning in adapting to climate variability and change in least developed countries. Planned adaptation to climate change denotes actions undertaken to reduce the risks and capitalize on the opportunities associated with global climate change (Fu"ssel, 2007). For scholars like Haughton and Counsell (2004) regional planning matters - it is a process fundamental to future place-making activities, providing a forum for deciding what types of future settlement patterns society wishes to see. Regional Planning potentially allows (Gabriel and Laugesen, 2000; Batabyal and Nijkamp, 2004; Church, 2010; Krueger, 2010; Mason, 2011): linkages between sectoral national planning and project planning and between physical and socio-economic and spatial linkages through which project impacts are expressed; the identification of the institutional arrangements necessary to ensure beneficial integration of projects into the economy of a sub-national area; and proper definition of the role that environmental land use Planning can play in regional development. Regional planning is meant to foster and sustain regional development and its success depends to a great extent upon the effectiveness with which geographic space and spatial relations are incorporated into development planning and management for the region (Gabriel and Laugesen, 2000; Roberts, 2006; Krueger, 2010; Mason, 2011). Moreover, Gabriel and Laugesen (2000) assert that for Regional Planning to full fill its potential to contribute to regional development it should incorporate.

Environmental Land Use Planning as a fully integral component. Karl and Ranne (2001) contend that promoting environmental gain can both bring about innovative solutions for environmental protection or improvement and help to satisfy social and economic needs which may also help to develop a more positive perception of the interdependencies between environment and development in the regional communities. There is a growing expectation that planning would play a central role in government policy for sustainable development (Albrechts, 2004; Haughton and Counsell, 2004; Williams and Millington, 2004). For regional planning to play a critical role in climate change adaptation in least developed countries, it should adhere to basic principles and values of sustainable regional planning. Some of the key values include open dialogue, accountability, collaboration, and consensus building (Albrechts, 2004). Certain basic principles for sustainable regional planning includes (Roberts, 2006: 784785): the desirability of minimizing the number and length of journeys: work, home and leisure activities should become more spatially concentrated; the necessity to reconsider the location of activities, such as retailing, to ensure that they are accessible by transport and located within residential communities; the need to reconsider the mix and location of economic activities and to segregate activities that generate environmental problems in order that they might benefit from collective solutions; the desirability of developing residential forms that accord with the best practice of location, layout and construction in order to achieve maximum efficiency in the use of energy and materials; and the generation of both hard and soft infrastructures that allow for the best use of natural resources, the recycling of waste materials and the substitution of physical movement by other forms of interaction.
Mainstreaming adaptation planning at regional level recognises that vulnerabilities and the capacity to respond are site-specific. Moreover, planning at this level can engage local government, businesses, NGOs and the community (Lebel et al., 2012). Rural and urban development planning will often have a different emphasis. For instance, in rural areas the focus is likely to be on livelihoods, reducing poverty and improving access to public services. Meanwhile, in urban areas, the focus could be on improving infrastructure and building residents' resilience to hazards (UNDP-UNEP, 2011 cited in Lebel et al., 2012).

Most recently there has been a shift towards less emphasis on planning prescription and control in favour of seeing planners' input as one of the many inputs required in the development process, valuing other forms of non-technical knowledge and seeking the involvement of community members in the definition of a common vision (Allen, 2003). In short, planning is seen (and practised) increasingly as an iterative, participatory and flexible process (Allen, 2003). Scholars of regional planning like Measham, et al. (2011) contend that a multiplicity of communities exist, differentiated (and frequently divided) by factors including gender, ethnicity, class, and age in a given region or location. They also assert that this complexity poses multiple challenges for adaptation planning, in terms of what adaptation means for different groups, who benefits and loses from adaptation, and above all, how to define legitimate adaptation options (Measham, et al., 2011).

A common objective of sub-national/regional area-based planning is to reconcile conservation and development objectives, such as supporting nature-based tourism or maintaining other ecosystem goods and services, while still supporting activities such as agriculture, aquaculture or forestry (Lebel et al., 2012). The presence of resilient natural or lessintensively managed ecosystems in the landscape can also be important to people's livelihoods and capacity to adapt. Hence, regional planning has a critical role in climate change adaptation in least developed countries.

\section{A CASE STUDY ON BEST PRACTICES OF MAINSTREAMING CLIMATE CHANGE ADAPTATION INTO REGIONAL DEVELOPMENT PLANNING}

The author critically reviewed one case study on mainstreaming climate change adaptation into development planning. Accordingly, the analysis report of regional climate change adaptation platform for Asia was critically reviewed to understand challenges and opportunities for mainstreaming adaptation to climate change into development planning in the Asia-Pacific region and draw lessons for other regions in Least Developed Countries (LDCs).

Home to over one billion people, and to 60 per cent of the world's poor (UNESCAP, 2009), the Asia-Pacific region is widely viewed as vulnerable to climate change (ADB 2009a, 2009b; USAID 2010:1; World Bank, ADB, and JICA, 2010 cited in Lebel et al., 2012). Lebel et al. (2012) assert that the rural poor in developing countries are vulnerable, as they depend on the productivity of climate - sensitive ecosystems for their livelihoods, including agriculture and fishery. They also contend that the urban poor are vulnerable to infrastructure and land development decisions that drive settlements into areas that are already exposed to flooding, landslides, and other climate-related disasters, or likely to become so. In both realms, poverty hinders access to education, health care and 
other important services and resources. They further affirm that poor countries often lack the knowledge and resources to adequately adapt to growing climate related risks, building up an "adaptation deficit". In this context, climate change exacerbates what are already significant challenges, and adds another layer of risk and uncertainty to efforts to achieve sustainable development (Lebel et al., 2012).

Planning processes and capacities vary substantially among countries. Nevertheless, the experiences of national, sub national and sectoral planning initiatives suggest that there are common challenges and opportunities to mainstreaming adaptation to climate change (Lebel et al., 2012). A few of the major lessons learned for development planning from theory and practices in the Asia-Pacific region are: A country or a region should give due attention to the needs and practical experience of practitioners to improve the relevance, accessibility and usefulness of climate information; A country or a region should encourage and support inclusion of local insight and knowledge into national, regional or local climate adaptation policies, strategies and planning; A country or a region should screen regional or local climate risks associated with policies, strategies, plans, programmes and projects to identify the extent to which climate change, risks and vulnerability have been considered or addressed; A country or a region should undertake thorough and well organised climate risk assessments to informational, regional or local development planning and help to identify and evaluate risks and adaptation options that are specific to the decision or national policy or regional strategy problem; A country or a region should start mainstreaming climate change adaptation with existing policies, plans and institutions, as these often embody important experiences and may already address key development issues; A country or a region should consider climate change as a development issue, rather than an environmental one for proper acknowledgement of the significance of the issue by decision-makers and given an adequate budget, and that responses will be integrated into development planning; A region or a country should properly manage the policy or strategy conflicts in the process of mainstreaming adaptation to climate change not to compromise government's priority development goals like poverty reduction and other development objectives; A country or a region should learn from climate change policy or strategy and adaptation plans and other policy and planning experiences in its region and recognize their limitations for future improvements; and A country or a region should properly monitor and evaluate climate adaptation projects in its region to check whether they meet their climate adaptation objectives, and what other benefits or adverse impacts they may have on the environment and development.

\section{NATIONAL AND INTERNATIONAL POLICY RESPONSES TO CLIMATE CHANGE IN BANGLADESH}

\subsection{National policy response options}

There is no comprehensive national policy in Bangladesh that specifically targets climate change risks. However, the Bangladesh government is aware of the importance of climate change, as well as the country's historical sensitivity to climate variability in general, and there are several policy response options that exist that relate to climate change. These include: indirectly addressing the impacts of climate change through programmes that reduce vulnerability through for example poverty alleviation, employment generation, crop diversification; directly addressing vulnerability to climate variability and extreme events through disaster risk reductions and management schemes; and specifically targeting climate change by mainstreaming climate change into sectoral plans and national policies. A selection of policies that reduce vulnerability to climate variability, and also specifically climate change, will be discussed here.

\subsection{Vulnerability Reduction}

In Bangladesh ongoing projects address food insecurity and food production shortfalls by crop diversification and generation of alternative employment opportunities aimed at community development, agricultural development, credit facilities, and infrastructure improvement. Fish and shrimp production for domestic consumption and exports are promoted with special emphasis on rural poverty alleviation and employment generation. All such developmental programmes are important in enhancing the resilience of the poor.

\subsection{Disaster Management and Climate Risk Management}

Bangladesh has a Participatory Disaster Management Programme (PDMP) with a focus on disaster management and prevention, and also adaptation to climate change. The focus is on 'soft' measures to reduce the impacts of disasters, with an emphasis on preparedness, such as: awareness raising of practical ways to reduce disaster risks and losses, to strengthen national capacity for disaster management; enhance knowledge and skills of personnel in handling disasters; establishing disaster action plans in the most disaster prone areas; promoting local-level risk reduction measures; and improving early warning systems.

In 2003 Bangladesh also established a Comprehensive Disaster Management Programme (CDMP) with UNDP and other donor assistance, with the aim of refocusing the government towards greater emphasis on disaster preparedness and risk reduction. CDMP has a number of disaster management components, among them to establish an integrated approach to climate change and disaster management, expanding risk reduction approaches across a broader range of hazards, with specific reference to climate change. There are three main areas of focus:

i. Capacity building for the Ministry of Environment and the Department of Environment to coordinate and mainstream climate change into their existing activities;

ii. Strengthening existing knowledge and information accessibility on impact prediction and adaptation;

iii. Awareness raising, advocacy and coordination to promote climate change adaptation into development activities.

Capacity building included assisting the creation of a 'climate change cell' within the Department of Environment (DoE) to build government capacity for coordination and leadership on climate change issues. The cell coordinates awareness raising, advocacy and mechanisms to promote climate change adaptation and risk reduction in development activities, as well as strengthening existing knowledge and information accessibility on impacts and adaptation to climate change.

The climate change cell is informed by another component of CDMP, the Local Disaster Risk Reduction Facility (LDRRF). LDDRF aims to improve coordination between developmentorientated and disaster management aspects of the Government of Bangladesh at the local level.

Bangladesh therefore has fairly effective mechanisms in place for disaster management and climate risk management (CRM), 
however, there is room to improve the functioning effectiveness of this system. The UNDP suggest that an Integrated National Framework for CRM and DRR, broader understanding of climate change risks and impacts at all levels, as well as capacity building for assessing risks and analysing them with sectoral and cross-sectoral perspectives and implications.

\subsection{Mainstreaming climate change into development and national planning}

The Bangladesh government is integrating climate change into sectoral plans and national policies. For example, recommendations from the World Bank (see below) on the impacts of climate change have been incorporated into coastal zone management programs and adopted in the preparation of disaster preparedness plans and a new 25 year water sector plan. In agriculture, research programs have taken place in light of climate change information, particularly drought and saline tolerant rice varieties. Bangladesh's interim poverty reduction strategy paper (I-PSRP) recognizes the direct link between poverty and vulnerability to natural hazards, and notes that the incidence of disasters is likely to increase rather than decrease as a result of global warming. The I-PSRP has been criticised for not specifically mentioning climate change in the context of planning vulnerability measures. However, in November 2007 the Government announced an initiative to formally incorporate the impacts of climate change into all development plans in PSRP revisions, proposing a draft policy and action plan by October 2008 .

Other national policies of relevance to climate change include: The National Water Policy (NWP), announced in 1999, which was the first comprehensive look at short, medium and ling term perspectives for water resources in Bangladesh; followed by the National Water Management Plan (NWMP) in 2001 that looked at the implementation and investment responses to address the priorities identified in the NWP. The NWP does not explicitly mention climate change, however climate change is recognised by the NWMP as one of the factors determining future water supply, including the impacts of sea level rise, which guides the implementation of the NWP. Further, many of the NWP and NWMP priorities are synergistic with climate change adaptation, such as the recommendation in the NWP for early warming and flood proofing systems. Other environmental policies, including the National Environmental Management Plan (NEMAP), the National Land Use Policy, and the National Forest Policy, do not make specific reference to climate change.

\subsection{Climate change policies, planning and institutions}

Bangladesh is signatory to the United Nations framework Convention on Climate Change (UNFCCC). In 1992, the Government of Bangladesh signed the UNFCCCC, and ratified in 1994. The Ministry of Environment and Forest (MOEF) is responsible for coordinating the UNFCCC process in Bangladesh. A National Climate Change Committee, comprised of members from all relevant government and nongovernment organizations, was constituted in 1994 for policy and guidance and to oversee the implementation of obligations under the UNFCCC process. In addition to the Climate Change Cell, other government institutions that are relevant for climate change include: an inter-ministerial committee on climate change, headed by the Minister for Environment an Forests and with representation from relevant government ministries as well as NGOs and research institutions; and a National Environment Committee to determine environmental policies chaired by the Prime Minister with representation from MPs as well as government and civil society.

Through these institutions as well as independently, the Government of Bangladesh, Academic Institutes, and Research Organisations have been a number of studies on impacts, adaptation and vulnerability to climate change, and participated in a range of national efforts that seek to address climate change directly. A selection of these is presented in Box 1.

Bangladesh has undertaken a number of significant projects and achieved several milestones in the area of climate change:

- $\quad$ Signed the UNFCCC on 09.06.1992 and ratified it on 15.04.1994

- Accessed the Kyoto Protocol on 21.08.2001.

- Participated in the US Climate Change Country Study Program and prepared its emission inventory and vulnerability assessment in 1994.

- Participated in the Asia Least Cost Green House Gas Abatement Strategy (ALGAS) Study in 1995-98. The ALGAS study included the formation of the national GHG abatement strategies consistent with national development priorities, and preparation of portfolio of GHGs abatement projects.

- Submitted its first National Communication to the UNFCCC in 2002. Bangladesh has taken up a project "Bangladesh: Climate Change Enabling Activity "Self Assessment Exercise" as a first step to prepare its Second National Communication in the near future.

- Completed a National Adaptation Plan of Action (NAPA) and has already submitted the NAPA to the UNFCCC in November 2005.

- Under the Clean Development Mechanism Bangladesh has established a two tier Designated National Authority (DNA). The tiers are National CDM Board and National CDM Committee. The DNA so far has approved four projects in waste and energy sectors of Bangladesh. These projects are at different stages of implementation. These projects are:

- Landfill Gas Extraction and Utilization at Matuail by Waste Concern

- Composting Project at Gazipur and Kanchpur by Waste Concern

- Installation of 30,000 Solar Home Systems (SHS) in rural households by Grameen Shakti and BCAS

- Promotion of Energy Efficient Compact Florescent Lamp (CFL) in Rural Bangladesh (100,000 incandescent lamps to be replaced by CFL) by Grameen Shakti and BCAS

Figure 1. National Efforts to Address Climate Change in Bangladesh (Box 1)

Notable among these efforts in relation to climate change impacts is that Bangladesh was the first country to complete a
National Adaptation Programmes of Action (NAPAs), which are documents produced by the Least Developed Countries for 
the UNFCCC to identify immediate and urgent needs for adaptation to climate change. Bangladesh successfully completed the NAPA in 2005.

\subsection{International policy response options}

This section will discuss the role of the United Nations Framework Convention on Climate Change (UNFCCC) as well as selected donor initiatives, in supporting climate change impacts responses in Bangladesh.

\subsection{The United Nations Framework Convention on Climate change}

The UNFCC is an international treaty that came of United Nations Conference on Environment and Development (UNCED), informally known as the Earth Summit, held in Rio de Janeiro in 1992. The UNFCCC addresses what can be done to reduce global warming and to cope with whatever temperature increases are inevitable. There are approximately

There are currently four funds for adaptation:

1. Least Developed Countries Fund (LDCF), established under the UNFCCC to help developing countries prepare and implement their National Adaptation Programmes of Action (NAPAs).

2. Special Climate Change Fund (SCCF), also established under the UNFCCC to support a number of climate change activities such mitigation and technology transfer, but place top priority on adaptation.

3. GEF Trust Fund's Strategic Priority for Adaptation (SPA) which pilots 'operational approaches' to adaptation.

4. Adaptation Fund (AF) which was established under the Kyoto Protocol and is intended to assist developing countries carryout 'concrete' adaptation activities.

The LDCF, SCCF and Trust Fund are based on voluntary pledges and contributions from donors. As of April 2007, the LDCF and SCCF amounted to around US\$114 million in received allocations [3]. All three funds are managed by the Washingtonbased Global Environment Facility (GEF) under the guidance of the UNFCCC. To carry out work under the funds the GEF works with its three Implementing Agencies, the World Bank, United Nations Environment Programme (UNEP), and the United Nations Development Programme (UNDP).

The AF fund is funded by a $2 \%$ levy on CDM transactions 1 . The $2 \%$ share of credits from the CDM transactions is collected directly by an international body - the CDM Executive Board - and transferred to the AF for monetization. The World Bank has estimated that the levy could generate funding in the range of US\$100-500 million through to 2012 [World Bank, 8]. The management of the Adaptation Fund was finalized at the thirteenth Conference of the Parties (COP 13) in Bali in December 2007, and will be operationalized in 2008.

40 Annex-1 and 150 Annex-2 Parties and Observes to the convention. The UNFCCC supports adaptation to the impacts of climate change primarily through four funds (see box 2):

Figure 2. Adaptation Funding under the UNFCCC (Box 2)

The UNFCCC funding streams for adaptation have been criticised for being financially and technically inadequate to meet the adaptation needs of developing countries. Oxfam estimates that the true monetary cost of adaptation could be in excess of $\$ 50$ billion annually, yet in 2007 the three GEF funds received pledges of approximately US \$200 million, and although the World Bank estimates that the amount of money available under the Adaptation Fund may amount to US \$100500 million by 2012 , this still falls significantly short of the estimated cost of adaptation.

Bangladesh's completion of the NAPA took place with financial assistance from the UNFCCC through the Least Developed Countries Fund (LCCF). However, because the preparation of full project design documents was not funded through the NAPA process, additional resources are still required to prepare full project documentation before implementation can take place.

Other relevant UNFCCC policies include the Nairobi Framework on Impacts, Vulnerability and Adaptation, that shall assist all countries but developing countries, the Least Developed Countries, and Small Island States, to improve their understanding on impacts, vulnerability and adaptation actions and measures to respond to climate change. The Nairobi Work Programme does not engage in implementation of concrete adaptation activities, but rather calls for a series of workshops and reports over the coming two years to share and analyse information on topics relevant to climate change adaptation.

\subsection{Climate change activities in selected donor strategies}

Bangladesh received over one billion USD of Official Development Assistance annually. Analysis of donor portfolios in Bangladesh carried out by the OECD in 2005 revealed that between 22 and 53 per cent of development assistance of aid amount, and 22 to 37 per cent of aid-funded projects, are in sectors potentially affected by climate risks. As early as 1996 the World Bank's 2002 Long-run Perspective Study for Bangladesh raised the issue of climate change, particularly the potential for the economic impacts of sea-level rise. In response, the World Bank sponsored the Bangladesh Climate Change and Sustainable Development Study (2000) which analysed the possible impacts of climate change, identified physical and institutional adaptation options, and reviewed a number of development projects and the National Water Management Plan, with the aim of mainstreaming adaptation in the regular development strategies and operations in Bangladesh.

The OECD notes that donor country strategies and project documents generally lack explicit attention to climate change. However, more recently and in line with increasing international attention to climate change, donors are increasing their focus on climate change in Bangladesh. For example, DfID Bangladesh has mainstreamed climate change activities into its development programmes; and also now provides direct support for programmes that reduce vulnerability to climate variability and climate change. DfID has screened its projects in Bangladesh based on profiles of climate and future hazard 
and vulnerability, and disaster risk reduction and climate change adaptation recommendations have been integrated into programme activities. The pilot programme for mainstreaming began in Bangladesh in 2006, and has now finished. DfID also provides funding for adaptation directly, for example through bilateral support for specific work on disaster management and climate change under the CDMP, described above. DfID is providing a total of $£ 5.7$ million over 5 years supporting a range of sub-elements in the programme, among them establishing an integrated approach to climate change and disaster management. Part of DfID's funding went towards two positions in the climate change cell, one of which specialises in climate change adaptation. Other examples of donor projects that incorporate climate change include: the GEF/UNDP Coastal and Wetland Biodiversity management at Cox' Bazar and Hakaluki Haor (2000 - 2007), which notes the potential effect of sea-level rise.

\section{IMPLICATIONS FOR MAINSTREAMING CLIMATE CHANGE ADAPTATION INTO REGIONAL DEVELOPMENT PLANNING OF REGIONS IN BANGLADESH}

Bangladesh is a country in South Asia. It faces the Bay of Bengal to its south, and is bordered by India on the north, west and east, as well as Myanmar on the southeast. It is separated from the Himalayan nations of Nepal and Bhutan by India's narrow siliguri corridor, and is in close geographical proximity to China.

Bangladesh's base of natural resources is the foundation of any economic development, food security and other basic necessities of its people. Agriculture is the dominant sector that provides over 85 percent of the total employment and foreign exchange earnings and approximately 55 percent of the Gross Domestic Product (GDP). As of recently the industry and service sectors are taking more share of the GDP (BBS, 2010). The population of Bangladesh as of 15 March 2011 is 142.3 million (census 2011 results; this is a preliminary figure which has been disputed by the UN and now by Bangladeshis themselves), much less than recent (2007-2010) estimates of Bangladesh's population ranging from 150 to 170 million and it is the 8th most populous nation in the world.

Bangladesh is a low-lying, coastal country. More than 80 percent of the land is situated on the deltas and floodplains of the Ganges, the Brahmaputra, and the Meghna (GBM) rivers. Every year, these rivers flood a majority of the delta areas. Bangladesh also receives large amounts of annual rainfall concentrated mostly during the four-month monsoon season from June through September, leading to loss of life, homes, and livelihoods, as well as increases in the spread of water- and vector-borne diseases. In contrast to the monsoon season, a lack of rainfall during drier months (October through May) causes droughts that lower crop yields, increase food stress and scarcity, and lead to higher food prices overall. The dry season is also associated with lower river flows, which allow for saline intrusion from the Bay of Bengal into the coastal rivers and agricultural land. In addition, strong storm surges from cyclones oft en ravage coastal areas, causing signify cant loss of lives and damage to property and livelihoods. Extreme high tides erode coastal lands and embankments.

Flooding, erosion, and saline intrusion all threaten Bangladesh's water infrastructure, which has frequently been breached during storms, cyclones, and floods that have led to complex humanitarian disasters (Nizamuddin, 2001). T e frequency and intensity of such storms are also predicted to increase; some reports state that this could lead to between six and eight million being permanently displaced by 2050 . This number could be even higher if coastal polders are not strengthened or reconstructed to accommodate for expected rise in sea level. According to another estimate, a combination of sea level rise, an increase in saline intrusion of freshwater sources, and an increase in cyclone and storm surges in the near future, threatens to displace more than 20 million people (BCCSAP, 2009).

Over the last 35 years, in response to routine natural disasters the GoB has adopted various policies and invested over $\$ 10$ billion to increase Bangladesh's resiliency. But increases in frequency and magnitude of extreme events like floods, river erosion, cyclones, and tidal surges (SPCR, 2010, p-11) due to climate change will require additional measures. These investments, in many cases supported by development partners, include flood management plans, coastal polders, cyclone and flood shelters, and the raising of roads and highways above expected flood levels. In addition, the GoB has developed state-of-the-art early warning systems for floods, cyclones, and storm surges, and is expanding community-based disaster preparedness programs. Climate resilient varieties of rice and other crops have also been developed.

For decades, Bangladesh has been affected by natural disasters, but climate change is causing an increase in the frequency and extremity of these events. While Bangladesh has made some progress to improve its population's well being and economic development, the impacts from climate change threaten to undermine many of these achievements. Particularly at risk are specific sectors including agriculture, water and sanitation, infrastructure, and health.

\subsection{Agriculture}

The vast majority of the population in Bangladesh depends on the agricultural sector for their livelihood, employing approximately 60 percent of the labor force. Approximately 1.2 million hectares of arable land in Bangladesh is used for agricultural production. The sector is extremely vulnerable to higher temperatures, changing rainfall patterns, increased flooding and drought, and rising salinity in coastal areas that affect crop yields and crop production. The Intergovernmental Panel on Climate Change (IPCC) estimates that by 2050, rice production in Bangladesh could decline by 8 percent and wheat by 32 percent (against a base year of 1990), which could lead to serious food insecurity (BCCSAP, 2009).

\subsection{Water Access and Sanitation}

Climate change will exacerbate water-related disasters such as flooding and drought. River bank erosion and saline water intrusion in the coastal areas are likely to displace hundreds of thousands of people. Additionally, a shortage of safe drinking water is likely to become more acute, especially in the southern coastal areas and drought-prone areas in the northwest.

In response to these threats, migration to urban areas is increasing as people search for new economic opportunities. However, they oft en end up in urban slums and will be among those most affected by climate change. Urban slums in Bangladesh are already overcrowded, poorly managed by municipal governments, and face severe constraints in providing water and sanitation services. 


\subsection{Infrastructure}

Sudden breaches in embankments have been destroying standing crops and inundating crop lands with saline water. In recent decades, Bangladesh has heavily invested in infrastructure that aims to build resilience to climate change, despite the risk that it will be frequently damaged by continual floods and more intense storms. As such, climate resilient investment in infrastructure carry a certain element of financial risk, but the potential cost of inaction are estimated to be more expensive (Agrawala et al., 2003).

\subsection{Health}

Climate change and resulting natural disasters are likely to increase the incidence of water-borne and vector-borne diseases. Saline intrusion of fresh drinking water will also lead to increased health hazards. In fact, the threat that floods pose in terms of increasing sicknesses and deaths from diarrhea, malaria, cholera, dengue fever, and the like, could eventually lead to exorbitant levels of spending on preventable public health epidemics (Rahman et al., 2002).

Ahmed, A.U (2010), contend that addressing current and future climate vulnerabilities in development planning and programming through mainstreaming of climate change adaptation should be an immediate priority for Bangladesh. Being prepared to adapt to climate change is important, even as the world strives to reduce the factors that cause it (Adem and Bewket, 2011).

According to Khan (2011), development - as - usual, without consideration of climate risks and opportunities, will lead to maladaptive practices weakening national resilience to climate change in Bangladesh. In a nut-shell, Bangladesh's endeavors to respond to the impacts of climate change through adaptation and mitigation policy frameworks are highly appreciable (Jessica, 2011). Nevertheless, the practical implementation of these policy frameworks is impaired by different challenges. Lack of sector-specific, region-specific and context-specific adaptation strategies, inadequate climate information, institutional limitations, lack of resources, a culture of reactive management, limited awareness and knowledge on climate change, limited participation of sectors and sub-national / regional bodies in national adaptation policy and strategies, and poor linkage between local-level impacts and national-level responses are to mention some Huq, 2008).

The author would like to propose the following climate change adaptation mainstreaming strategic measures for regions in Bangladesh to overcome the aforementioned challenges: Each region in Bangladesh should give due attention to the needs and practical experience of practitioners to improve the relevance, accessibility and usefulness of climate information; Each region in Bangladesh should encourage and support inclusion of local insight and knowledge into regional or local climate adaptation strategies and planning; Each region in Bangladesh should screen regional or local climate risks associated with strategies, plans, programmes and projects to identify the extent to which climate change, risks and vulnerability have been considered or addressed; Each region in Bangladesh should undertake thorough and well organized climate risk assessments to inform regional or local development planning and help to identify and evaluate risks and adaptation options that are specific to the decision or regional strategy problem; Each region in Bangladesh should start mainstreaming climate change adaptation with existing policies, plans and institutions, as these often embody important experiences and may already address key development issues; Each region in Bangladesh should consider climate change as development issue, rather than an environmental one to acknowledge its significance by decisionmakers and given an adequate budget, and that responses will be integrated into development planning; Each region in Bangladesh should properly manage the strategy conflicts in the process of mainstreaming adaptation to climate change not to compromise regional government's priority development goals like poverty reduction and other development objectives; Each region in Bangladesh should learn from climate change strategy and adaptation plans and other policy and planning experiences in its region and recognize their limitations for future improvements; and Each region in Bangladesh should properly monitor and evaluate climate adaptation projects in its region to check whether they meet their climate adaptation objectives, and what other benefits or adverse impacts they may have on the environment and development.

\section{CONCLUSION}

This study explored the seek for mainstreaming climate change adaptation into regional planning of least developed countries and proposed strategic measures for mainstreaming climate change adaptation into regional development planning of regions in Bangladesh.

Mainstreaming adaptation into development planning has been promoted as an effective way to respond to climate change and the expected benefits for least developed countries include: avoided policy conflicts; reduced risks and vulnerability; greater efficiency compared with managing adaptation separately; leveraging the much larger financial flows in sectors affected by climate risks than the amounts available for financing adaptation separately, and easier to start with existing policies and practices, rather than creating new ones. Least developed countries should therefore do more to prepare for ongoing and future climate changes focusing on actions that are no-regrets, multi-sectoral and multi-level, and that improve the management of current climate variability.

Strengthening capacities to use climate information, enabling locally appropriate responses, screening climate risks, assessing risks and adaptation options, starting with existing policies and plans, broadening constituencies beyond environment agencies, managing strategy conflicts, learning from projects and recognizing their limitations, monitoring and learning are the foreseen strategic actions by regions in Bangladesh for effective mainstreaming of climate change adaptation into regional development planning in the years to come.

\section{REFERENCES}

1. Aalst MKV, Cannon T, Burton I (2008). Community level adaptation to climate change: The potential role of participatory community risk assessment. Global Environmental Change 18, 165-179

2. In: Lim, B., Spanger-Siegfried, E., Burton, I., Malone E, Huq S (2004). (ed). Adaptation Policy Frameworks for Climate Change: Developing Strategies, Policies and Measures. New York: United Nations Development Programme

3. Adem A, Bewket W (.2011). A Climate Change Country Assessment Report. Addis Ababa: Epsilon International R and $\mathrm{D}$ 
4. Adem A, Guta A (2011). Engendering Climate Change Policy and Practice. Addis Ababa: Forum for Environment.

5. Adger N, Huq S, Brown K, Conway D, Hulme M (2002). Adaptation to climate change: Setting the Agenda for Development Policy and Research. Tyndall Centre for Climate Change Research, Working Paper 16. Norwich: Tyndall Centre for Climate Change Research.

6. Adger W N, Huq S, Brown K., Conwaya D, Hulmea M (2003). Adaptation to climate change in the developing world. Progress in Development Studies 3, 3, 179-195

7. Ahmed, A., U. (2004). A review of the current policy regime in Bangladesh in relation to climate change adaptation, Reducing Vulnerability to Climate Change (RVCC) Project, CARE Bangladesh, Khulna

8. Ahmed, A.U., (2006). Bangladesh: Climate Change Impacts and Vulnerability - A Synthesis, Climate Change Cell, Department of Environment, Government of Bangladesh, Dhaka 3, 65- 70

9. Ahmed, A.U., (2011). Institutional Framework to Advance Adaptation in Bangladesh, in G.A. Chowdhury, A. Hassan, and A.U. Ahmed (eds.), Climate Change Risks and Adaptation in Bangladesh, Centre for Environmental Geographic Information Services (CEGIS), Dhaka.

10. Albrechts, L (2004). Strategic (spatial) planning reexamined. Environment and Planning B: Planning and Design 31, 743- 758

11. Allen A (2003). Environmental planning and management of the periurban interface: perspectives on an emerging field. Environment and Urbanization 15, 135-148

12. Batabyal AA, Nijkamp P (2004). The environment in regional science: An eclectic review. Papers Reg. Sci. 83, 291-316

13. Betsill MM, Bulkeley H (2006). Cities and the Multilevel Governance of Global Climate Change. Global Governance 12, 141-159

14. Brooks N, Adger WN, Barnett J, Woodzard LB (2004). Assessing and Enhancing Adaptive Capacity. In: Lim, B., Spanger-Siegfried, E., Burton I., Malone, E. and Huq,S.2004(ed). Adaptation Policy Frameworks for Climate Change: Developing Strategies, Policies and Measures. New York: United Nations Development Programme

15. Bulkeley H, Mol APJ, (2003). Participation and Environmental Governance: Consensus, Ambivalence and Debate. Environmental Values 12: 143-54

16. Chinvanno S, (2011). Mainstreaming Climate Change into Community Development Strategy: A critical opinion on climate change adaptation planning and case study in Thailand. Bangkok, Thailand: Southeast Asia START Regional Center

17. Church JM (2010). Environmental Regionalism: The Challenge of the Alpine Convention and the "Strange Case" of the Andean Community. CID Research Fellow and Graduate Student Working Paper No. 47. Center for International Development at Harvard University

18. Claire MC, Reynolds R, Wiedmer D (2002). Poverty and Climate Change: Assessing Impacts in Developing Countries and The Initiatives of the International Community. London: The Overseas Development Institute.

19. Denton F (2002). Climate change vulnerability, impacts, and adaptation: why does gender matter? Gender and Development 10, 2,10 20.
20. Downing TE, Patwardhan A, Klein RJT, Mukhala E, Stephen L, Winograd M, Ziervogel G (2004). Assessing Vulnerability for Climate Adaptation. In: Lim, B., Spanger-Siegfried, E., Burton, I., Malone, E. and Huq, S. 2004(ed). Adaptation Policy Frameworks for Climate Change: Developing Strategies, Policies and Measures. New York: United Nations Development Programme.

21. Ebi KL, Lim B, Aguilar Y, Burton I, deboer G, Dougherty B, Huq S, Spanger-Siegfried E, Lonsdale K (2004). Scoping and Designing an Adaptation Project.

22. Lim, B., Spanger-Siegfried, E., Burton, I., Malone, E. and Huq, S (2004). (ed). Adaptation Policy Frameworks for Climate Change: Developing Strategies, Policies and Measures. New York: United Nations Development Programme

23. Economic Commission for Europe (ECE) (2009). Convention on the Protection and Use of Trans boundary Watercourses and International Lakes: Guidance on Water and Adaptation to Climate Change. New York and Geneva: United Nations.

24. Elasha BO, (2010). Mapping of Climate Change Threats and Human Development Impacts in the Arab Region. Arab Human Development Report, Research Paper Series. Regional Bureau for Arab States: United Nations Development Programme.

25. Energy Group of ECSNCC Netzork (2011). Renewable Energy and Climate Change Nexus. Addis Ababa: Gaia Association

26. DoE (2012). National Report of Bangladesh, the United Nations Conference on Sustainable Development (Rio+20)

27. Eriksen SH, Brown K, Kelly PM (2005). The Dynamics of Vulnerability: Locating Coping Strategies in Kenya and Tanzania. The Geographical Journal 171, 4, 287-305

28. Few R, Brown K, Tompkins EL (2006). Public Participation and Climate Change Adaptation. Working Paper 95. Norwich: Tyndall Centre for Climate Change Research

29. Füssel HM (2007). Adaptation planning for climate change: concepts, assessment approaches, and key lessons. Sustain Sci, 1-11.

30. Gabriel J, Laugesen CH (2000). Integrated Environmental Planning: A Regional Perspective. A Paper Presented at the Environmental Convention held in Kuching, Sarawak, 29-30 June 2000. Sabah, Malaysia: State Environmental Conservation Department (ECD).

31. Gigli S, Agrawala S (2007). Stocktaking of Progress on Integrating Adaptation to Climate Change into Development Co-operation Activities. Paris: OECD.

32. Haines A, Kovats RS, Campbell-Lendrum D, Corvalan C (2006). Climate change and human health: Impacts, vulnerability and public health. Public Health 120, 585596.

33. Hardoy J, Pandiella G (2009). Urban poverty and vulnerability to climate change in Latin America. Environment \&and Urbanization 21, 1, 203-224

34. Haughton G, Counsell D (2004). Regions and Sustainable Development: Regional Planning Matters. The Geographical Journal 170, 2, 135-145.

35. Heltberg R, Siegel PB, Jorgensen SL (2009). Addressing human vulnerability to climate change: Toward a 'noregrets' approach. Global Environmental Change 19, 8999

36. Huq S, Rahman A, Konate M, Sokona Y, Reid H (2003). Mainstreaming Adaptation to Climate Change in Least Developed Countries (LDCs). London: The International 
Institute for Environment and Development Climate Change Programme

37. Huq, S. \& Ayers, J. (2008). Taking steps: mainstreaming national adaptation. IIED Briefing. [internet] Available at http://www.iied.org/pubs/pdfs/17040IIED.pdf

38. Huq, S., (2001). Climate Change and Bangladesh, Science, 294(5547): 1617

39. Huq, S., Ahmed, A.U. and Koudstaal, R., (1996). Vulnerability to Bangladesh to Climate Change and Sea level rise. Climate Change and World Food Security, T.E. Downing (Ed), NATO ASI Series 1(37). Springer-Verlag. Berlin, Heidelberg 1996. 5, 347-379.

40. Huxtable J, Yen NT (2009). Mainstreaming Climate Change Adaptation: A Practioner's Handbook. Ha Noi, Vietnam: CARE International in Vietnam.

41. IPCC. (2007). Climate Change 2007: Impacts, Adaptation and Vulnerability. Contribution of Working Group II to the Fourth Assessment Report of the Intergovernmental Panel on Climate Change, Annex I., M.L. Parry, O.F. Canziani, J.P. Palutikof, P.J. van der Linden and C.E. Hanson, Eds. Cambridge University Press, Cambridge, UK.

42. Jones R, Boer R, Magezi S, Mearns L (.2004). Assessing Current Climate Risks. In: Lim, B., Spanger-Siegfried, E., Burton, I., Malone, E., and Huq,S.2004(ed). Adaptation Policy Frameworks for Climate Change: Developing Strategies, Policies and Measures. New York: United Nations Development Programme

43. Karl H, Ranne O (2001). Regional Policy and the Environment: The Case of Germany. Eur. Env. 11, 103111.

44. Keim ME (2008). Building Human Resilience: The Role of Public Health Preparedness and Response as an Adaptation to Climate Change. Am J Prev Med 35, 5,508516.

45. Kidanu A, Rovin K, Hardee K (2009). Linking Population, Fertility and Family Planning with Adaptation to Climate Change: Views from Ethiopia. Addis Ababa and Washington, DC: Miz-Hasab Research Center (MHRC) and Population Action International (PAI)

46. Klein RJT, SEL, Dessai S (2003). Integrating mitigation and adaptation into climate and development policy: three research questions. Working Paper 40. Norwich: Tyndall Centre for Climate Change Research.

47. Kok M, Metz B, Verhagen J, Rooijen SV (2008). Integrating development and climate policies: national and international benefits. Climate Policy, 8,103-118.

48. Krueger R (2010). Smart Growth and Its Discontents: An examination of American and European Approaches to Local and Regional Sustainable Development. Doc. Anàl. Geogr. 2010, 56, 3, 409-433.

49. Lebel L, Li L, Krittasudthacheewa C, Juntopas M, Vijitpan T, Uchiyama into Krawanchid D ( 2012). Mainstreaming Climate Change Adaptation Development Planning. Bangkok: Adaptation Knowledge T, Platform and Stockholm Environment Institute.

50. Lim B, Spanger-Siegfried E, Burton I, Malone E, Huq S (2004) (ed). Adaptation Policy Frameworks for Climate Change: Developing Strategies, Policies and Measures. New York: United Nations Development Programme.

51. Mackaye B (1940). Regional Planning and Ecology. Ecological Monographs 10, 3, 349-353.

52. Malone EL, Rovere EL (2004). Assessing Current and Changing Socio- Economic Conditions. In: Lim, B., Spanger-Siegfried, E., Burton, I., Malone, E. and
Huq,S.2004(ed). Adaptation Policy Frameworks for Climate Change: Developing Strategies, Policies and Measures. New York: United Nations Development Programme

53. Mason RJ (2011). Ecoregional Planning: Retreat or Reinvention? J. Planning Literature 26,4, 405-419

54. Measham TG, Preston BL, Smith TF, Brooke C, Gorddard R, Withycombe G, Morrison C (2011). Adapting to climate change through local municipal planning: barriers and challenges. Mitig Adapt Strateg Glob Change, 1-21

55. Ministry of Finance and Economic Development (MoFED). (2010). Growth and Transformation Plan (GTP) 2010/11-2014/15: Draft. Addis Ababa: MoFED)

56. Mirza MMQ (2003). Climate change and extreme weather events: can developing countries adapt? Climate Policy 3, 233-248

57. MoEF, (2005). National Adaptation Programme of Action (NAPA). Ministry of Environment and Forests, Government of the People's Republic of Bangladesh, Dhaka, Bangladesh. Available at http://unfecc.int/resource/docs/napa/ban01.pdf

58. Nelson V (2011). Gender, Generations, Social Protection \&and Climate Change: A Thematic Review. London: Overseas Development Institute

59. Oates N, Conway D, Calow R (2011). The 'mainstreaming' approach to climate change adaptation. Overseas Development Institute Background Note. London: ODI

60. Pandey DN, Gupta AK, Anderson DM.(2003). Rainwater Harvesting as an Adaptation to Climate Change. Current Science 85, (1), 10, 46- 59.

61. Roberts P (2006). Sustainable Regional Planning. Regional Studies 28, 8, 781-787

62. Revi A (2008). Climate change risk: an adaptation and mitigation agenda for Indian cities. Environment and Urbanization 2008, 20, 1, 207-229.

63. Schipper L, Liu W, Krawanchid D, Chanthy S (2010). Review of climate change adaptation methods and tools. MRC Technical Paper No. 34. Vientiane: Mekong River Commission

64. Thomasa DSG, Twyman C (2005). Equity and justice in climate change adaptation amongst natural-resourcedependent societies. Global Environmental Change 15, $115-124$

65. Tompkins EL, Adger WN (2003). Defining response capacity to enhance climate change policy. Tyndall Centre Working Paper No. 39. Norwich: Tyndall Centre for Climate Change Research

66. Turnpenny J, Haxeltine A, Lorenzoni I, O'Riordan T, Jones M (2005). Mapping actors involved in climate change policy networks in the UK. Norwich: Tyndall Centre for Climate Change Research

67. U.S. Agency for International Development (USAID). 2004. Adapting to Climate Variability and Change: A Guidance Manual for Development Planning. Washngton, DC: USAID

68. UNDP (United Nations Development Programme). 2004. Adaptation Policy Frameworks for Climate Change. Cambridge, UK: Cambridge University Press

69. UNPEI (United Nations Development Programme-United Nations Environment Programme Poverty-Environment Initiative). 2011. Mainstreaming Climate Change Adaptation into Development Planning: A Guide for Practitioners. Nairobi, Kenya: UNDP-UNEP 
70. Williams, C. C,. and Millington, A.C. (2004). The Diverse and Contested Meanings of Sustainable Development. The Geographical Journal 170, 2, 99-104.

71. Yaro JA, Dogbe TD, Bizikova L, Bailey P, Ahiable G, Yahaya T, Salam KA (2010). Development and Climate
Change: The Social Dimensions of Adaptation to Climate Change in Ghana. Discussion Paper Number 15, December 2010. Washington, DC; World Bank 